\title{
Combinations using checkpoint blockade to overcome resistance
}

\author{
Stefania Morganti ${ }^{1,2}$ and Giuseppe Curigliano $0^{1,2}$ \\ ${ }^{1}$ Division of Early Drug Development for Innovative Therapies, European Institute of Oncology (IEO), IRCCS, Via Ripamonti n.435, 20141, Milan, Italy \\ ${ }^{2}$ Department of Oncology and Hemato-Oncology, University of Milan, Via Festa del Perdono n. 7, 20122 Milan, Italy
}

\section{Abstract}

The advent of immunotherapy for cancer represented a paradigm shift in the treatment approach of neoplasia. Immune-checkpoint inhibitors (ICls) were demonstrated to significantly improve outcomes, including overall survival across several cancer types, with yearly-durable responses. Nevertheless, many patients derive minor or no benefit with immune checkpoint (IC)-blockade, including patients with cancer types traditionally considered immunogenic. Combination strategies of $\mathrm{ICls}$ with chemotherapy, radiotherapy, targeted therapies or other immunotherapy compounds have been conceived in order to boost the immune-responses and potentially overcome resistance to ICls. This review focuses on mechanisms underlying resistance to IC-blockade and provides an overview of potential advantages and limitations of combination strategies currently under investigation.

Keywords: chemo-immunotherapy, immune-checkpoint inhibitors, immunotherapy combinations, immunotherapy resistance, next-generation immune modulators, NGIM, targeted therapy

\section{Introduction}

Cancer is a genetic disease, resulting from a multistep tumorigenesis with the selection for clonal malignant cells capable of uncontrolled proliferation, survival, invasion and metastatic potential [1]. Genomic alterations responsible for malignant transformation frequently occur in somatic cells; however, the environmental and spontaneous mutagenesis and expansion of malignant clones are actively supervised by the immune system, able to tackle cancer development and spreading by recognizing and killing individual aberrant cells.

The interaction between cancer cells and the immune system has been elegantly described as a self-propagating cyclic process by Chen and Mellman [2]. This process starts with the release of cancer cell antigens and ends with the killing of tumour cells. Acquisition of immune-stimulating factors occurs during the cycle, leading to anti-tumour T-cell response amplification. On the other hand, the onset of inhibitory signals can generate negative regulatory feedback mechanisms and halt the development or limit the immune response.
Correspondence to: Giuseppe Curigliano Email: Giuseppe.curigliano@ieo.it

ecancer 2020, 14:1148

https://doi.org/10.3332/ecancer.2020.1148

Published: 03/12/2020

Received: 07/12/2019

Publication costs for this article were supported by ecancer (UK Charity number 1176307).

Copyright: (c) the authors; licensee ecancermedicalscience. This is an Open Access article distributed under the terms of the Creative Commons Attribution License (http:// creativecommons.org/licenses/by/3.0), which permits unrestricted use, distribution, and reproduction in any medium, provided the original work is properly cited. 
The balance between immune-stimulating and immune-suppressing factors drives the immune response against cancer. This dynamic relation has been defined 'immunoediting' [3] and is described as a three-phase process: elimination (immune surveillance with clearance of the malignant clones), equilibrium (tumour control with no radical clearance of the clones) and escape (immune-system evasion and tumour progression). Progression from the first two phases to the last one is marked by acquisition of new mutations that allow malignant cells to evade immune-recognition and start uncontrolled proliferation.

Diverse escape mechanisms [3] harbouring immunosuppressive functions have been described. Inter alia, the activation of immune-checkpoints (ICs) like cytotoxic T lymphocyte-associated protein-4 (CTLA-4) or programmed cell death protein-1 (PD-1) represents one of the best characterised mechanisms of immune escape, with therapeutic implications. The development of drugs targeting the ICs, like the class of IC inhibitors (ICls), marked the history of cancer treatment, achieving results never seen in terms of durable responses and long survival across several cancer histologies. Albeit largely effective in a subset of long-responding patients with selected histologies, many cancer types seem to be insensitive to these agents, while others develop resistance.

The aim of this review is to describe main combination strategies currently under development to overcome resistance to ICls.

\section{ICls: mechanism of action and resistance}

ICls are monoclonal antibodies (mAbs) targeting checkpoint proteins expressed by immune cells or tumour cells, such as PD-1, programmed cell death protein-ligand 1 (PD-L1) and CTLA-4. These proteins are physiologically expressed by immune-competent cells to maintain immunological homeostasis and prevent autoimmunity [4,5], but their upregulation is a well-characterized mechanism of tumour immune-escape [6]. ICls are able to reactivate T-cell mediated immune response by interrupting co-inhibitory signalling pathways and allowing the killing of tumour cells $[7,8]$.

The pharmaceutical landscape of development of ICls is complex, with the recent approval of a multitude of ICls used as single agents, in combination with other ICls or with standard treatments. Additionally, the use of pembrolizumab has been Food and Drug Administrationapproved for treatment of all tumour types, regardless of the original site of origin and histology, if harbouring microsatellite instability-high (MSI-h) tumours. This approval by the food and drug administration (FDA) has represented the first tissue/site-agnostic approval in the oncology field [9].

Approved ICl combinations are presented in Table 1.

The introduction of ICl-based therapy in the clinical setting has revolutionized the history of oncology, leading to long-term responses and improving survival in a wide range of cancer types. Nevertheless, only $10 \%-30 \%$ of all treated patients derive meaningful clinical benefit from immunotherapy, and only a small subset of them truly achieves long-term survival outcomes. Moreover, many tumours show primary or acquired resistance to ICls.

In particular, primary resistance occurs when patients progress rapidly and/or do not benefit at all from exposure to immune-regulating agents, whereas secondary resistance refers to cases of relapse and progress after an initial response [10].

The principal causes of primary resistance to ICls include lack of effective tumour-related antigens, needed for T-cell recognition of the altered selfmaterial, and absence of infiltrating T cells, in a way that interactions between the immune system and cancer cells cannot occur. These cancers are commonly called 'cold' tumours, to distinguish them from effectively immune-infiltrated 'hot' tumours. In the continuum between 'cold' and 'hot' tumours, an intermediate phenotype called 'altered' has been proposed, in which immune cells are unable to infiltrate the tumour properly ('excluded' phenotype) or the immunosuppressive environment limits effector actions of T-cells ('immunosuppressed' phenotype) [11] (Figure 1).

In this context, the term 'adaptive resistance' refers to all the situations in which cancer cells can be potentially recognised by infiltrating T-cells, but other mechanisms concur to build an immune-suppressive milieu [10]. Adaptive resistance can occur ab initio or develop during treatment with IC-blockade, as a form of acquired resistance. Some well-characterized mechanisms of adaptive resistance have been reported, such as loss of tumour antigen [12]- or human leukocyte antigen (HLA) [13]- expression, constitutive expression of co-inhibitory proteins [14], alterations of intracellular signalling pathways (Mitogen-Activated Protein Kinase (MAPK) [15], Phosphoinositide 3-Kinase (PI3K) [16], WNT/ $\beta$-catenin [17]) and anti-inflammatory cytokines secretion by immune suppressive cell populations (regulatory T-cells [18], myeloid derived stem cells [19], type II macrophages [20]) in the tumour microenvironment (TME). While some of these mechanisms are prevalent in certain tumour types, for the majority of immune-resistant tumours multiple causes overlap and act synergistically. 
Table 1. Approved combination of ICI (September 2019).

\begin{tabular}{|c|c|c|c|}
\hline Trial & Regimen & Disease and setting & Results \\
\hline $\begin{array}{l}\text { KEYNOTE-189 } \\
\text { Gandhi et al [45]. } \\
\text { Gadgeel et al [139]. }\end{array}$ & $\begin{array}{l}\text { Pembrolizumab plus pemetrexed and platinum } \\
\text { CT }\end{array}$ & $\begin{array}{l}\text { Metastatic non-squamous NSCLC, with } \\
\text { no EGFR and anaplastic lymphoma } \\
\text { kinase (ALK) genomic alterations }{ }^{\mathrm{a}} \\
\text { First-line treatment }\end{array}$ & $\begin{array}{l}\text { mPFS } 8.8 \text { versus } 4.9 \text { months } \\
\text { (HR } 0.52 ; 95 \% \mathrm{Cl}, 0.43-0.64) \\
\text { mOS } 22 \text { versus } 10.7 \text { months } \\
\text { (HR } 0.56 ; 95 \% \mathrm{Cl} 0.45-0.70)\end{array}$ \\
\hline $\begin{array}{l}\text { KEYNOTE-407 } \\
\text { Paz-Ares et al [46]. }\end{array}$ & $\begin{array}{l}\text { Pembrolizumab plus carboplatin and paclitaxel } \\
\text { or nab-paclitaxel }\end{array}$ & $\begin{array}{l}\text { Metastatic squamous NSCLC } \\
\text { First-line treatment }\end{array}$ & $\begin{array}{l}\text { mOS } 15.9 \text { versus } 11.3 \text { months } \\
\text { (HR 0.64; } 95 \% \mathrm{Cl}, 0.49-0.85)\end{array}$ \\
\hline $\begin{array}{l}\text { IMpower150 } \\
\text { Socinski et al [47]. }\end{array}$ & $\begin{array}{l}\text { Atezolizumab plus bevacizumab, paclitaxel and } \\
\text { carboplatin } \\
\text { (versus bevacizumab plus paclitaxel plus } \\
\text { carboplatin) }\end{array}$ & $\begin{array}{l}\text { Metastatic non-squamous NSCLC, with } \\
\text { no EGFR and ALK genomic alterations }{ }^{\mathrm{a}} \\
\text { First-line treatment }\end{array}$ & $\begin{array}{l}\text { mOS } 19.2 \text { versus } 14.7 \text { months } \\
\text { (HR } 0.78 ; 95 \% \mathrm{Cl}, 0.64-0.96)\end{array}$ \\
\hline $\begin{array}{l}\text { IMpower130 } \\
\text { West et al [48] }\end{array}$ & $\begin{array}{l}\text { Atezolizumab plus paclitaxel and carboplatin } \\
\text { (versus paclitaxel plus carboplatin) }\end{array}$ & $\begin{array}{l}\text { Metastatic non-squamous NSCLC, with } \\
\text { no EGFR and ALK genomic alterations }{ }^{c} \\
\text { First-line treatment }\end{array}$ & $\begin{array}{l}\text { mOS } 18.6 \text { versus } 13.9 \text { months } \\
\text { (HR 0.79; } 95 \% \mathrm{Cl} 0.64-0.98)\end{array}$ \\
\hline $\begin{array}{l}\text { IMpower133 } \\
\text { Horn et al [49] }\end{array}$ & $\begin{array}{l}\text { Atezolizumab plus carboplatin and etoposide } \\
\text { (versus carboplatin plus etoposide) }\end{array}$ & $\begin{array}{l}\text { Extensive-stage } \mathrm{SCLC}^{\mathrm{a}} \\
\text { First-line treatment }\end{array}$ & $\begin{array}{l}\text { mOS } 12.3 \text { versus } 10.3 \text { months } \\
\text { (HR } 0.70 ; 95 \% \mathrm{Cl} 0.54-0.91)\end{array}$ \\
\hline $\begin{array}{l}\text { KEYNOTE-048 } \\
\text { Burtness et al [50] }\end{array}$ & $\begin{array}{l}\text { Pembrolizumab plus platinum and fluorouracil } \\
\text { (versus platinum plus fluorouracil plus cetux- } \\
\text { imab) }\end{array}$ & $\begin{array}{l}\text { Metastatic or unresectable, recurrent } \\
\text { HNSCC }^{\text {a }} \\
\text { First-line treatment }\end{array}$ & $\begin{array}{l}\text { mOS } 13 \text { versus } 10.7 \text { months } \\
\text { (HR 0.77; } 95 \% \mathrm{Cl} 0.63-0.93)\end{array}$ \\
\hline $\begin{array}{l}\text { IMpassion130 } \\
\text { Schmid et al [140] } \\
\text { Schmid et al [141] }\end{array}$ & $\begin{array}{l}\text { Atezolizumab plus nab-paclitaxel } \\
\text { (versus nab-paclitaxel) }\end{array}$ & $\begin{array}{l}\text { Metastatic or unresectable TNBC with } \\
\text { PD-L1 } 1 \%^{\mathrm{a}} \\
\text { First-line treatment }\end{array}$ & $\begin{array}{l}\text { mPFS ITT } 7.2 \text { versus } 5.5 \text { months } \\
\text { (HR 0.8; } 95 \% \mathrm{Cl} 0.69-0.92 \text { ) } \\
\text { mPFS PDL1+ } 7.5 \text { versus } 5 \text { months } \\
\text { (HR 0.62; } 95 \% \mathrm{Cl}, 0.49-0.78 \text { ) } \\
\text { mOS ITT } 21 \text { versus } 18.7 \text { months } \\
\text { (HR 0.86, } 95 \% \mathrm{Cl} 0.72-1.02 \text { ) } \\
\text { mOS PDL1+ } 25 \text { versus } 18 \text { months } \\
\text { (HR } 0.71,95 \% \mathrm{Cl} 0.54-0.94 \text { ) }\end{array}$ \\
\hline $\begin{array}{l}\text { CheckMate-067 } \\
\text { Wolchok et al [142] } \\
\text { Larkin et al [123] }\end{array}$ & $\begin{array}{l}\text { Nivolumab plus ipilimumab } \\
\text { (versus nivolumab alone versus ipilimumab } \\
\text { alone) }\end{array}$ & Metastatic or unresectable melanoma ${ }^{a}$ & $\begin{array}{l}\text { mPFS } 11.5 \text { versus } 6.9 \text { versus } 2.9 \\
\text { months } \\
(\text { HR 0.43; } 95 \% \mathrm{Cl} 0.35-0.52)^{\mathrm{d}} \\
\text { mOS NR versus } 36.9 \text { versus } 19.9 \\
\text { months } \\
(\text { HR } 0.52 ; 95 \% \mathrm{Cl} 0.42-0.62)^{\mathrm{d}}\end{array}$ \\
\hline $\begin{array}{l}\text { CheckMate-214 } \\
\text { Motzer et al [124] }\end{array}$ & $\begin{array}{l}\text { Nivolumab plus ipilimumab } \\
\text { (versus sunitinib) }\end{array}$ & $\begin{array}{l}\text { Advanced RCC at intermediate or poor } \\
\text { risk }^{\text {a }} \\
\text { First-line treatment }\end{array}$ & $\begin{array}{l}\text { mOS NR versus } 26.6 \text { months } \\
\text { HR 0.66; 95\% Cl } 0.54-0.80 \\
\text { mPFS } 8.2 \text { versus } 8.3 \text { months } \\
\text { HR } 0.77 ; 95 \% \mathrm{Cl} 0.65-0.90 \\
\text { ORR } 42 \% \text { versus } 29 \%\end{array}$ \\
\hline $\begin{array}{l}\text { CheckMate-142 } \\
\text { Overman et al [125] }\end{array}$ & $\begin{array}{l}\text { Nivolumab plus ipilimumab } \\
\text { (non randomized) }\end{array}$ & $\begin{array}{l}\text { MSI-H or dMMR metastatic CRC pro- } \\
\text { gressed on fluoropyrimidine, oxaliplatin } \\
\text { and irinotecan }{ }^{\mathrm{b}}\end{array}$ & $\begin{array}{l}\text { ORR 55\%, mDOR NR } \\
\text { 12-months PFS 71\% }\end{array}$ \\
\hline $\begin{array}{l}\text { KEYNOTE-426 } \\
\text { Rini et al [120] }\end{array}$ & $\begin{array}{l}\text { Pembrolizumab plus axitinib } \\
\text { (versus sunitinib) }\end{array}$ & $\begin{array}{l}\text { Advanced RCCa } \\
\text { First-line treatment }\end{array}$ & $\begin{array}{l}\text { mPFS } 15.1 \text { versus } 11.1 \text { months } \\
\text { HR 0.69; } 95 \% \mathrm{Cl} 0.57-0.84\end{array}$ \\
\hline $\begin{array}{l}\text { JAVELIN Renal101 } \\
\text { Motzer et al [119] }\end{array}$ & $\begin{array}{l}\text { Avelumab plus axitinib } \\
\text { (versus sunitinib) }\end{array}$ & $\begin{array}{l}\text { Advanced } \mathrm{RCC}^{\mathrm{a}} \\
\text { First-line treatment }\end{array}$ & $\begin{array}{l}\text { mPFS } 13.8 \text { versus } 8.4 \text { months } \\
\text { HR } 0.69 ; 95 \% \mathrm{Cl} 0.56-0.84\end{array}$ \\
\hline
\end{tabular}

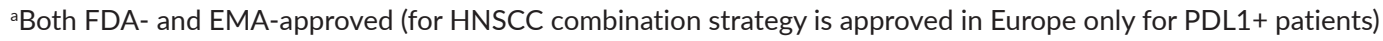

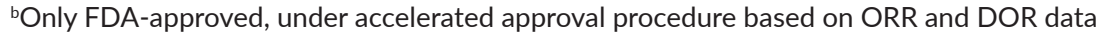

'Only EMA-approved

${ }^{\mathrm{d}} \mathrm{HR}$ for nivo/ipi versus ipi

mOS: median Overall Survival 


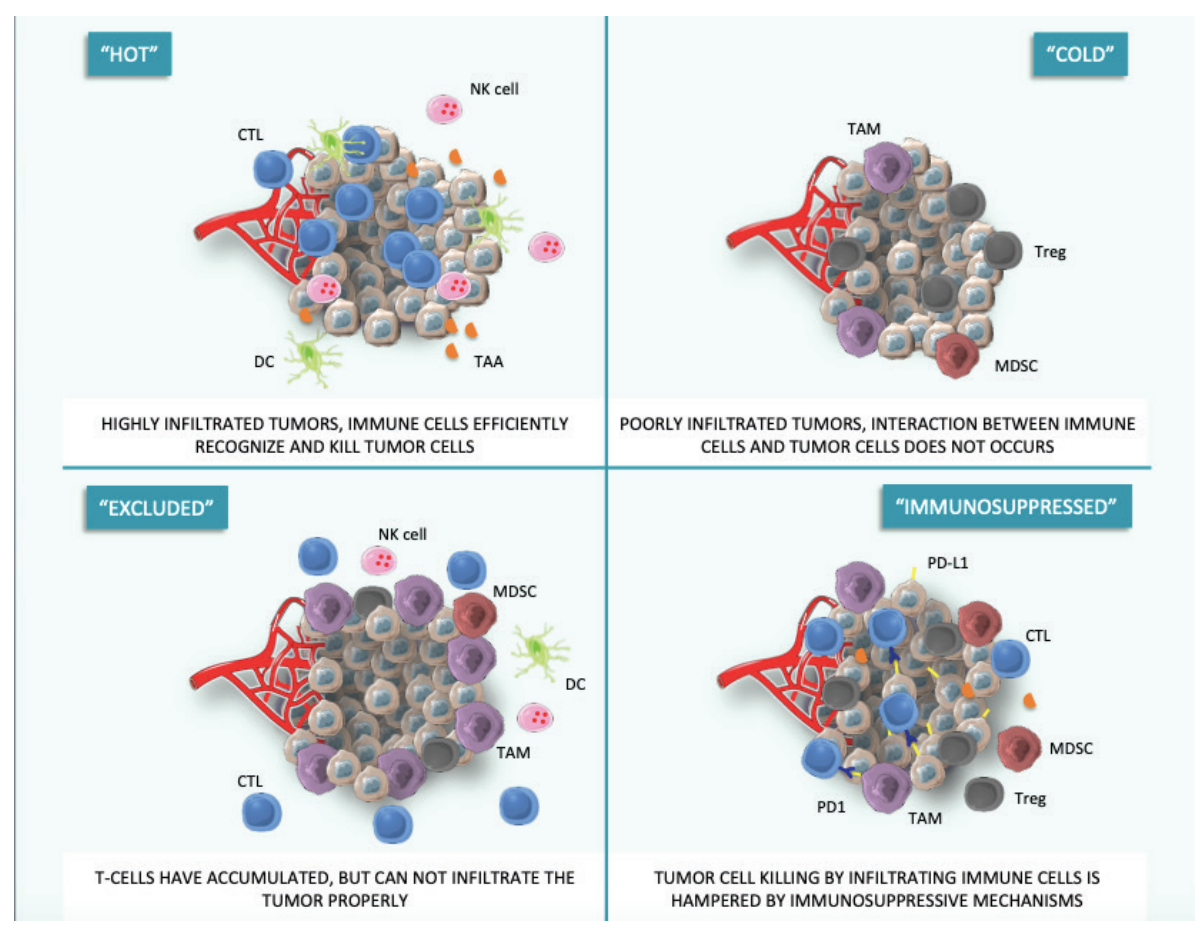

Figure 1. Hot, cold and adapted tumour phenotypes. This figure was created using Servier Medical Art templates, which are licensed under a Creative Commons Attribution 3.0 Unported License; https://smart.servier.com.

In order to reverse these mechanisms and overcome resistance to $\mathrm{ICl}$ monotherapy, new combination strategies have been explored, integrating ICls with different agents such as radiotherapy, chemotherapy, targeted agents or new-generation immune-modulators.

\section{Chemotherapy plus ICls}

Chemotherapy (CT) comprises a large group of drugs with different mechanisms of action and targets. Historically, preclinical trials testing CT agents did not consider the potential interactions between CT and the immune system, and these drugs have been mainly developed in vitro and through immunodeficient mice. Similarly, early phase trials in human have broadly analysed the adverse effects on immune-competent cells, such as on the white blood cells count, missing the pharmacodynamics of CT-host immune system interactions. A stronger interest regarding the potential immunomodulatory effect of CT has emerged quite recently, following the 'immunotherapy revolution' of last years. CT can both increase immunogenicity of tumour cells and inhibit immunosuppressive features induced in the TME.

Firstly, some CT agents demonstrated to enhance tumour-infiltration, expansion and activity of effector cells like cytotoxic T-lymphocytes (CTLs), dendritic cells (DCs) and natural killer (NK) cells, exerting immune-modulating properties. Cyclophosphamide [21], gemcitabine [22], platinum compounds [23], taxanes [24] and methotrexate 25] have all demonstrated to recruit DCs in the TME, induce their maturation and increase antigen presentation. Treatment with taxanes [26] and cyclophosphamide [27] also leads to increased NK cells activity. Moreover, 5-fluorouracil [28], taxanes [29] and cisplatin [30] have been found to increase the concentration of tumour-infiltrating lymphocytes (TILs), suggesting to facilitate the recruitment of immune-competent cells with a role in mounting an anti-cancer response.

Cancer cells can escape immune-surveillance by inducing a TME dominated by immune-suppressive cells, like regulatory T-cells (Tregs), myeloid-derived suppressor cells (MDSCs) and M2-polarized macrophages. 
CT has the potential to deplete the immune-suppressive cell populations. Cisplatin [30], cyclophosphamide [31], taxanes [32], gemcitabine [33], anthracyclines [34] reduce Tregs infiltration and functionality. An augmented CTLs/Tregs ratio has been observed after administration of taxanes [35] and oxaliplatin [36]. Vincristine and dacarbazine suppress tumour-associated macrophages [37]. Finally, taxanes [38], 5-fluorouracil [39], gemcitabine [40] and cisplatin [30] have been demonstrated to deplete the tumour from MDSCs.

Apart from actions on immune cells, CT can stimulate immunogenicity of tumour cells by increasing tumour-associated antigens production, release and presentation to immune-component cells. Immunogenic cell death (ICD) is a form of cell death induced by CT and RT, characterized by secretion of damage-associated molecular pattern proteins, which in turn trigger antitumour immunity by recruiting DCs into the tumour bed and stimulating tumour antigens up-taking, processing and presentation to T cells. Anthracyclines [41], cyclophosphamide [21, 27] and oxaliplatin [42] are powerful inducer of ICD.

Tumour cells can suppress the antigen presentation and T-cell recognition by losing major histocompatibility complex (MHC) I expression on cell surface, a known mechanism of immune escape. Another way to increase tumour immunogenicity shared by several $\mathrm{CT}$ drugs is restoration of $\mathrm{MHC}$ I expression $[43,44]$.

Following these evidences, several studies tested CT in combination with ICls and, as expected, their co-administration was found to act synergistically to induce tumour cell killing and durable responses. Chemo-immunotherapy regimens have shown superiority to first-line CT in several cancer types, with manageable toxicities [45-50]. Table 1 reports all chemo-immunotherapy approved regimens with corresponding indications.

Interestingly, immune-modulating action of CT seems to be related to both dose and schedule of administration. Two in vivo studies showed how synergistic effects are maintained only when CT is administered before ICls or concomitantly, whereas they are lost if administered after it $[51,52]$. An induction phase seems to be necessary to maximise tumour killing. Regarding optimal dose of CT, some clinical evidences showed an increased efficacy for low-dose regimens, namely metronomic regimens, boosting the immune system without inducing myelosuppression [53].

The phase II TONIC trial, conducted in the metastatic setting of triple-negative breast cancer, investigated the potential role of short-term 'induction' or 'priming' with CT or radiation in modulating the anticancer immune response to ICls. The induction phase consisted in 2 weeks of low-dose CT administration (cisplatin, doxorubicin or cyclophosphamide), RT versus no treatment. Response rates were higher in the cohorts treated with low-dose CT, compared with nivolumab alone, suggesting an immune-enhancing activity. Biomarker analysis showed also a higher number of infiltrating CTLs [54].

CT induction strategies aiming at transforming 'cold' into 'hot' tumours to potentiate their sensitivity to ICls are currently being tested in several tumour types. For instance, in the ARETHUSA [55] (NCT03519412) and MAYA (NCT03832621) trials, patients with MGMT-silenced microsatellite-stable (MSS) metastatic colorectal cancers ( $\mathrm{MCRCs}$ ) receive an induction treatment with single-agent temozolomide (TMZ), followed in the absence of disease progression by the combination of TMZ with CTLA-4 plus PD-1 blockade (MAYA trial) or by pembrolizumab at the time of tumour mutational burden (TMB) high-associated disease progression (ARETHUSA trial). While MSI-high mCRCs are sensitive to ICls blockade, MSS mCRCs usually are not. The investigators hypothesized that induction treatment of MSS-MGMT hypermethylated mCRCs with alkylating agents like TMZ could alter the tumour genetic landscape by increasing TMB, leading to potential sensitisation to ICls blockade [56].

\section{Radiotherapy plus ICls}

Radiotherapy (RT) has many important indications in cancer treatment, both in the curative and palliative setting. For the metastatic diseases, the aim of RT is to improve local control and relieve cancer-related symptoms like pain or bleeding. After the advent of immunotherapy, a renewed interest emerged in the potential role of RT in modulating the immune system.

Whereas RT has been historically considered mainly suppressive because of deep lymphodepletion in irradiated sites, recent studies showed instead a more complex interaction. 
RT causes death of both tumour and immune cells. A relative increase in locally suppressive immune-cell is recorded immediately after RT, because of their lower immune-sensitivity. Despite this, a rapid repopulation by other lymphocyte subsets occurs, with recruitment of circulating effector immune cells. A phenotype change in tumour cells survived to RT also occurs, with an increased recognition by surrounding T-cells [57]. Finally, RT induces local secretion of inflammatory cytokines [58] by immune cells, increasing immune sensitisation further.

Besides local effects, RT can trigger immune killing outside the irradiated site, providing a so-called 'abscopal effect': this phenomenon, firstly described by R. H. Mole in 1953, consists on systemic responses induced by RT but in distant sites not irradiated [59]. A potential correlation between the abscopal effects and an immune stimulation was firstly proposed in 2004, after the observation that this phenomenon does not occur in T cell-deficient mice [60]. The abscopal effect can be assimilated to an 'in situ vaccination': RT induces an immunogenic-cell death, with the subsequent release of immunogenic factors. These molecules then trigger an antigen-specific immune response at a systemic level, beyond the sites of irradiation.

In recent years, several clinical experiences combining RT and IC-blockade have further corroborated the relation between the abscopal effect and a systemic immune activation. Formenti et al [61] enrolled patients with metastatic chemo-refractory NSCLC and reported a higher response rate in patients who received RT plus ipilimumab than ipilimumab alone or with CT. In head and neck squamous cell carcinoma (HNSCC) response rate was also higher when pembrolizumab was combined with RT than administered alone, as emerged from the PEMBRO-RT study [62]. However, a similar trial testing nivolumab plus RT versus nivolumab alone in the same tumour type did not recorded any advantage in terms of responses or progression-free survival from the combination therapy [62].

In addition, the PACIFIC trial showed a statistically significant and clinically meaningful benefit from the addition of maintenance durvalumab after chemo-radiation for locally advanced NSCLC [63].

CT and RT act synergistically to increase immune recognition of tumour cells, by inducing an ICD, increasing antigen recognition and reducing activity of immune-suppressive cells. However, PD-L1 is usually upregulated by these treatments, hampering action of T-cell. Administration of ICls after CT-RT removes this inhibition, rearming effector cells against tumour cells.

Doses, time and fractioning can also influence the immune effect of RT. Some preclinical evidences showed higher concentration of tumourinfiltrating T cells after single dose $[64,65]$ than in conventional fractionated low-dose regimens. However, other studies proved the opposite, with better results achieved with fractionated RT [66, 67]. With regard to timing of RT administration, a shorter interval between radiation and $\mathrm{ICl}$ administration seems to increase efficacy. In the PACIFIC trial, better outcomes were recorded when durvalumab was initiated within $\leq 2$ weeks of RT rather than $>2$ weeks after [63].

These evidences teach us that RT can potentially improve efficacy of IC-blockade, both increasing tumour immunogenicity and triggering the immune system. Nevertheless, more studies are needed to understand which is the best strategy to adopt.

\section{Targeted agents plus ICls}

Similarly to what previously exposed for CT and RT, also targeted agents interact with the immune system.

Targeted agents are mainly monoclonal antibodies ( $\mathrm{mAb}$ ), able to induce an immune response because of their intrinsic nature independently from the target. By binding both immune cells (through the Fc-gamma receptor) and tumour cells, mAb can induce the so-called antibodydependent cellular cytotoxicity (ADCC) reaction, by which the release of perforin and granzyme induces an immune-mediated tumour cell killing [68, 69]. Specific polymorphisms of Fc-gamma receptor have been associated to improved mAb effector functions [70].

Monoclonal antibodies can also stimulate complement-dependent cytotoxicity: the complement proteins can bind the Fc region of the mAb, inducing the assembly of the membrane attack complex and finally the tumour cell lysis [71].

An increased expression of proteins involved in tumour antigen processing has also been associated to targeted therapies. For instance, cetuximab therapy was shown to increase expression of transporter associated with antigen processing (TAP)1/2 [72], whereas vemurafenib demonstrated to induce calnexin and calreticulin proteins [73], all involved in antigens processing. Moreover the same drugs were associated to increased expression of MHC class I and II [74, 75]. Also the qualitative pool of tumour-associated antigens presented was found to be altered by targeted drugs, in a way that makes tumour cells more recognizable by effector cells [76]. 
Regarding PDL1 expression, some evidences demonstrated a reduced expression when these agents were administered, whereas others found the opposite [77, 78].

Finally, targeted agents were shown to influence the immune infiltrate, both depleting immunosuppressive cells [79] and recruiting effector immune cells [80], as well as eliciting immunogenic cell death [81].

A synergistic effect induced by the combination of ICls and TT has been demonstrated in several preclinical experiences [82, 83], leading to the design of clinical trials aimed at investigating the outcome of this synergism in terms of efficacy and tolerability.

An initial phase I trial tested the combination of ipilimumab and vemurafenib in patients with metastatic BRAF-mutated melanoma [84], but it was stopped early because of excessive toxicity. Other studies combining BRAF-inhibitors (BRAFi) and ipilimumab with or without MEKinhibitors (MEKi) showed similar results in terms of toxicity, with a high rate of G3-4 colitis and hepatic toxicity [85, 86]. Combinations of BRAFi, MEKi and anti-PD(L)1 were instead better tolerated, with promising results in terms of response rate [87]. Two different triple combined therapies are currently under investigation by two phase III randomized trials (COMBI-I-NCT02967692; and TRILOGY IMspire150NCT02908672).

As previously reported for CT and RT, also in these trials the sequence of administration between TT and IC-blockade seemed to impact on both efficacy and toxicity.

Non-squamous NSCLC is a clinical model of oncogenic-addicted cancer, for which gene alterations driving the tumorigenesis are well characterized and molecular drugs targeting their products are widely used in clinical practice. While targeted therapy has impressively improved outcomes in these diseases [88-90], immunotherapy seems to be not effective in the majority of patients with oncogene-addicted NSCLC [91]. Genomic alterations found in NSCLC have been mostly associated to lower mutational load and immunogenicity [92-94], with poorer response rates observed for patients harbouring these mutations in all clinical trials using ICls.

Epidermal growth factor receptor (EGFR)-mutated NSCLC are essentially 'immune-excluded' cancers [94]. EGFR-mutation can induce PDL1 expression [95], but the very low rate of TILs along with the low number of neo-antigens makes IC-blockade ineffective [96, 97]. Similarly, the combination of anti-EGFR tyrosine kinase inhibitor (TKI) plus ICls does not significantly improve activity versus targeted therapy alone, with instead a more severe toxicity [98-100].

ALK-rearranged NSCLCs have a similar immune-excluded phenotype and do not benefit from ICI treatment [96]. However, preclinical studies showed that ALK inhibitors (ALKi) could enhance T-cell infiltration and proliferation, with also an increased cytokine production [101]. Several early phase trials showed a high response rate with the combination of ALKi and ICls, but at the cost of severe toxicities [102, 103]. The administration of new generation ALKi with ICls seemed instead to be well tolerated, with promising efficacy data [104].

With the purpose of exploit the off-target immune stimulation of targeted agents, some trials are testing such combinations also in patients otherwise not eligible for these drugs. For instance, an ongoing trial is investigating the combination of durvalumab + monalizumab + cetuximab in RAS mutated metastatic CRCs (NCT02671435). Preclinical data have shown that monalizumab can enhance the ADCC activity of cetuximab; and in turn tumour cell death induced by cetuximab can potentially lead to release of tumour antigens and finally stimulate the antitumour immune response [105].

A similar strategy has been pursued also in BRAF-wt melanoma. A phase III trial (NCT03273153) testing the combination of cobimetinib and atezolizumab versus pembrolizumab alone has been designed, following promising preclinical and phase I data [106] showing an enhanced antitumour immune response to ICls induced by MAPK inhibition. However, this trial did not meet the primary endpoint of progression-free survival (PFS), and $\mathrm{G} \geq 3$ adverse events were more common with the combination than with pembrolizumab (67\% versus 33\%) [107].

\section{Antiangiogenic drugs plus ICls}

Angiogenesis processes are typically upregulated by tumours in order to provide nutrients and oxygen to proliferating cancer cells [1]. Drugs targeting the vascular endothelial growth factor (VEGF), a key regulator of angiogenesis in cancer, can inhibit this mechanism and reduce tumour growth, with favourable outcomes also in terms of survival in different cancer types [108]. 
Several preclinical evidences have described a strong interaction between angiogenesis mechanisms and the immune system. VEGF secretion not only blocks T-cell development and infiltration into the tumour, but also induces proliferation of immune-suppressive cells, like MDSCs and Tregs $[109,110]$. The administration of antiangiogenic drugs like sunitinib or cabozantinib can reverse this immune-suppression, both increasing intratumoural effector cells, decreasing PDL1 expression and reducing infiltrating MDSCs and Tregs [111-114].

A potential synergism between antiangiogenic drugs and ICls has been confirmed in preclinical models [115], leading to the development of clinical trials in different cancer types.

In patients with renal cell carcinoma (RCC), safety and efficacy of combined treatment with IC-blockade and antivascular agents have been extensively investigated. Several phase I trials demonstrated the feasibility and promising activity of such combinations, which consequently moved to first-line setting [116-118]. Results from two big phase III trials, the JAVELIN Renal 101 [119] and the KEYNOTE-426 [120], have been recently presented. Both of them used sunitinib as standard arm, whereas axitinib was associated to avelumab or pembrolizumab, respectively, as first-line regimen of treatment. Median PFS was significantly higher in the experimental arm in both trials, whereas median overall survival (OS) is still not reached. The median PFS observed in the pembrolizumab plus axitinib arm (15.2 m) was the highest everobserved in mRCC. Toxicity was not significantly increased in the combination arm in both trials.

A significant median OS advantage from the combination of atezolizumab plus bevacizumab has been recently reported also in patients with advanced hepatocellular carcinoma [121].

\section{Combination of different ICls}

CTLA-4 and PD-1/PD-L1 checkpoints act on different phases of immune activation: CTLA-4 regulates T-cell proliferation in the early phases of immune response, primarily in lymph nodes, whereas PD-1/PD-L1 axis acts later, primarily in peripheral tissues or into the TME [122]. These differences provide the rationale for combining anti-PD(L)1 with anti-CTLA4 mAbs, with a supposed additive or synergic action in immune stimulation. Clinical trials testing ipilimumab plus nivolumab firstly showed improved and durable responses in patients with advanced melanoma (ORR 58\%, median duration of response NR), with a significantly increased OS (median OS not reached after 60 months of median follow up) [123].

Despite these exciting data, this combination is not universally recognized as standard first-line regimen because of its safety profile. In the CheckMate-067 trial, G3-4 adverse events (AEs) were observed in 55\% of patients in the combination arm, versus $16 \%$ and $27 \%$ of patients treated with nivolumab or ipilimumab monotherapy, respectively. Moreover, evidences about a significant advantage of combination therapy over anti-PD-1 alone are weak, given that the CheckMate-067 trial was not powered to identify differences between these two regimens. Also for other tumour types in which this combination is approved, such as mRCC and MSI-h CRC, this superiority cannot be affirmed: in RCC nivolumab plus ipilimumab was tested versus sunitinib [124], and in MSI-h CRCs no comparison arms were present [125].

'Next-generation immune-modulators' (NGIMs) are antibodies targeting signalling pathways other than PD-(L)1 and CTLA4, involved in immune stimulation or suppression. Several co-stimulatory and co-inhibitory molecules with a recognized role in the interaction between tumour and the immune system have been characterized, and many of these pathways have been linked to adaptive resistance to ICblockade [126]. These drugs are commonly also defined 'second-generation ICls', but because of their action extended beyond checkpointinhibition the term 'immune modulation' should be preferred. Despite recent progresses, the understanding of complex biology underlying these pathways is still far from complete, and for most of them the identification of all associated ligands/receptors and the exact mechanism of action remain unresolved.

All of these molecules can be classified on the basis of their primary action, as co-stimulatory or co-inhibitory, and distinguishing cells in which they are predominantly expressed: lymphoid cells, NK cells or non-lymphoid cells (innate immune system, tumour cells or cells in the TME) [126]. Some of them are expressed on T-cell surface and act similarly to checkpoint inhibitors, like T cell immunoglobulin and mucin domain-containing protein 3 (TIM3), Lymphocyte-activation gene 3 (LAG3), T-cell immunoglobulin and ITIM domain (TIGIT) and V-domain 
Ig suppressor of T cell activation (VISTA) [127]. Other molecules act instead modulating the TME, regulating chemokine secretion (CXCR4, CXCL12) [128], concentration of metabolic products (Indoleamine 2,3-dioxygenase 1 (IDO1) [129] or activity of innate effectors or immunesuppressive cells (NGK2A [130], Colony stimulating factor 1 receptor (CSF1R) [131]).

NGIMs are currently tested in combination with anti-PD(L)1 mAb, in response to preclinical evidences showing a potential synergic action. The combination of nivolumab and anti-LAG3 relatlimab is under investigation in several cancer types, with preliminary data showing encouraging efficacy in patients with melanoma progressing on previous ICls [132]. Similarly, treatment with MBG453, an anti-TIM3 mAb, and spartalizumab showed good tolerability and preliminary signs of anti-tumour activity in a phase I trial enrolling all solid tumours [133]. Unfortunately these data were not confirmed in the phase II study testing the same combination in melanoma and NSCLCs progressed on PD-(L)1 therapy [134]. Other anti-TIM3 mAb are under investigation (Sym023, TSR-022 and LY3321367).

IDO1 is a rate-limiting enzyme converting tryptophan to kynurenine. High concentrations of kynurenine in the TME has been linked to T-cell anergy and resistance to ICls [129]. After preclinical and early clinical promising evidences of efficacy, the IDO1-inhibitor epacadostat has been tested in combination with pembrolizumab versus pembrolizumab alone in a large phase II/III trial. This trial failed to demonstrate any advance with the combination therapy [135].

Description of mechanisms of action and available evidences of all of NGIMs under development is beyond the aim of this review, and welldescribed elsewhere [126].

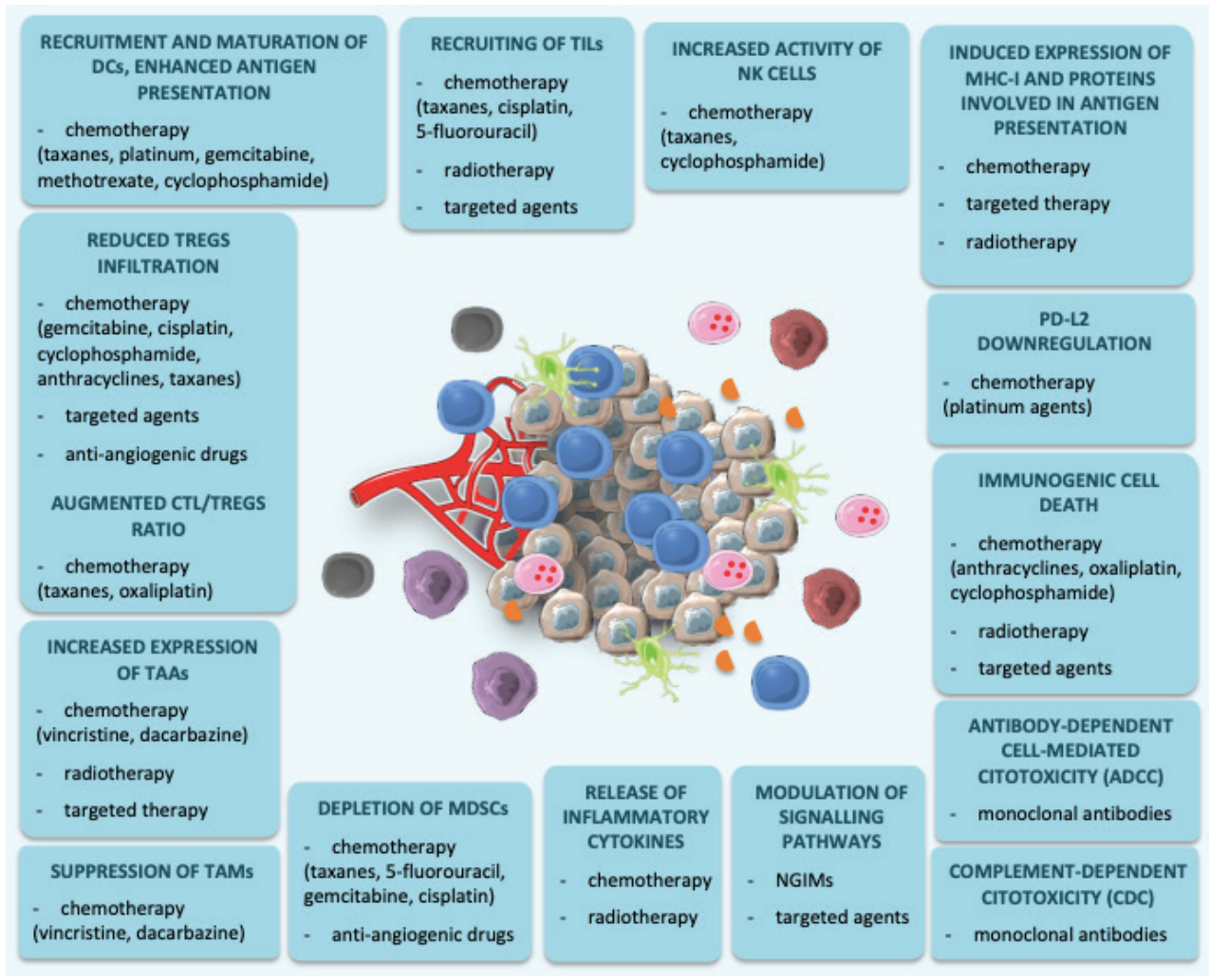

Figure 2. Immunological effects of CT, RT, targeted agents and new-generation immune modulators. This figure was created using Servier Medical Art templates, which are licensed under a Creative Commons Attribution 3.0 Unported License; https://smart.servier.com. 


\section{Conclusion}

Despite impressive results observed with ICls in several cancer types, still many patients do not achieve responses or eventually develop adaptive resistance. New combination strategies between ICls and different agents have been conceived in order to overcome this resistance and increase the percentage of patients that can benefit from immunotherapy. Combination of ICls with CT, RT, targeted agents or NGIMs showed a potential synergistic activity in preclinical series, leading to the design of several clinical trials. As previously reported, some strategies lead to a real clinical benefit, whereas others were disappointing because of inefficacy or excessive toxicity.

Although progresses of recent years shed a bit of light in this complex landscape, there are many open questions that need to be addressed. Optimal doses and timing of administration of such combinations are still uncertain. Some evidences seemed to suggest that both CT and RT could be more immunogenic at lower than standard doses, but no comparative big trials are available.

Combination therapies previously reported demonstrated to increase activity and efficacy, but usually at the cost of higher toxicity. In some settings, immunotherapy alone proved to significantly increase survival outcomes, and the question of whether a combination strategy is needed for all patients has been raised. For instance, both immunotherapy alone and IT-CT combinations are available first-line options for advanced NSCLC with PD-L1 expression higher than 50\%, and no comparative trial is available. Subgroups analysis and meta-analysis suggest that women, never smokers, patients with tumour-related symptoms or heavy tumour burden seem to mostly benefit from a combination strategy in this setting [45, 46, 136-138].

Another challenge is about how to combine or sequence ICls with other agents. In melanoma, the triple combinatorial therapy with BRAFi plus MEKi and ICls demonstrated to increase anti-tumour activity but with an increased toxicity [87]; therefore, a sequential strategy could be the preferential choice if efficacy is maintained.

Comparisons between different combination strategies are also lacking. In mRCC both the combination of nivolumab plus ipilimumab and axitinib plus anti-PD1 increased outcomes versus sunitinib in the first-line setting, but no direct comparison is available and choices in clinical practice are mainly derived from differences emerged in subgroup analysis.

In conclusion, combinations between ICls and different agents such as CT, RT, target agents or NGIMs demonstrated to increase efficacy of immune response against cancer, and potentially overcome resistance to single-agent immunotherapy (Figure 2). However, several questions are still unanswered, and future research should be directed to identify the best strategy in terms of dose, timing, duration and sequence of administration.

\section{Funding}

This work was partially supported by the Italian Ministry of Health with Ricerca Corrente and 5x1000 funds.

\section{References}

1. Hanahan D and Weinberg RA (2000) The hallmarks of cancer Cell 100 57-70 https://doi.org/10.1016/S0092-8674(00)81683-9 PMID: 10647931

2. Chen DS and Mellman I (2013) Oncology meets immunology: the cancer-immunity cycle Immunity 39 1-10 https://doi.org/10.1016/j. immuni.2013.07.012

3. Dunn GP, Bruce AT, and Ikeda H, et al (2002) Cancer immunoediting: from immunosurveillance to tumor escape Nat Immunol $3991-$ 998 https://doi.org/10.1038/ni1102-991 PMID: 12407406

4. Francisco LM, Sage PT, and Sharpe AH (2010) The PD-1 pathway in tolerance and autoimmunity Immunol Rev 236 219-242 https://doi. org/10.1111/j.1600-065X.2010.00923.x PMID: 20636820 PMCID: 2919275

5. Romo-Tena J, Gómez-Martín D, and Alcocer-Varela J (2013) CTLA-4 and autoimmunity: new insights into the dual regulator of tolerance Autoimmun Rev 12 1171-1176 https://doi.org/10.1016/j.autrev.2013.07.002 PMID: 23851140 
6. Dong H, Strome SE, and Salomao DR, et al (2002) Tumor-associated B7-H1 promotes T-cell apoptosis: a potential mechanism of immune evasion Nat Med 8 793-800 https://doi.org/10.1038/nm730 PMID: 12091876

7. Leach DR, Krummel MF, and Allison JP (1996) Enhancement of antitumor immunity by CTLA-4 blockade Science (80) 271 1734-1736 https://doi.org/10.1126/science.271.5256.1734 PMID: 8596936

8. Iwai Y, Ishida M, and Tanaka Y, et al (2002) Involvement of PD-L1 on tumor cells in the escape from host immune system and tumor immunotherapy by PD-L1 blockade Proc Natl Acad Sci USA 99 12293-12297 https://doi.org/10.1073/pnas.192461099 PMID: 12218188 PMCID: 129438

9. Marcus L, Lemery SJ, and Keegan P, et al (2019) FDA approval summary: Pembrolizumab for the treatment of microsatellite instabilityhigh solid tumors Clin Cancer Res 25 3753-3758 https://doi.org/10.1158/1078-0432.CCR-18-4070 PMID: 30787022

10. Sharma P, Hu-Lieskovan S, and Wargo JA, et al (2017) Primary, adaptive, and acquired resistance to cancer immunotherapy Cell 168 707-723 https://doi.org/10.1016/j.cell.2017.01.017 PMID: 28187290 PMCID: 5391692

11. Galon J and Bruni D (2019) Approaches to treat immune hot, altered and cold tumors with combination immunotherapies Nat Rev Drug Discov 18 197-218 https://doi.org/10.1038/s41573-018-0007-y PMID: 30610226

12. Anagnostou V, Smith KN, and Forde PM, et al (2017) Evolution of neoantigen landscape during immune checkpoint blockade in nonsmall cell lung cancer Cancer Discov 7 264-276 https://doi.org/10.1158/2159-8290.CD-16-0828 PMCID: 5733805

13. Paulson KG, Voillet $V$, and McAfee MS, et al (2018) Acquired cancer resistance to combination immunotherapy from transcriptional loss of class I HLA Nat Commun 9 https://doi.org/10.1038/s41467-018-06300-3 PMID: 30250229 PMCID: 6155241

14. Koyama S, Akbay EA, and Li YY, et al (2016) Adaptive resistance to therapeutic PD-1 blockade is associated with upregulation of alternative immune checkpoints Nat Commun https://doi.org/10.1038/ncomms10501

15. Liu C, Peng W, and Xu C, et al (2013) BRAF inhibition increases tumor infiltration by T cells and enhances the antitumor activity of adoptive immunotherapy in mice Clin Cancer Res 19 393-403 https://doi.org/10.1158/1078-0432.CCR-12-1626

16. Peng W, Chen JQ, and Liu C, et al (2016) Loss of PTEN promotes resistance to T cell-mediated immunotherapy Cancer Discov $6202-$ 216 https://doi.org/10.1158/2159-8290.CD-15-0283

17. Spranger S, Bao R, and Gajewski TF (2015) Melanoma-intrinsic $\beta$-catenin signalling prevents anti-tumor immunity Nature 523 231-235 https://doi.org/10.1038/nature14404 PMID: 25970248

18. Chaudhary B and Elkord E (2016) Regulatory T cells in the tumor microenvironment and cancer progression: role and therapeutic targeting Vaccines 428 https://doi.org/10.3390/vaccines4030028 PMCID: 5041022

19. Meyer C, Cagnon L, and Costa-Nunes CM, et al (2014) Frequencies of circulating MDSC correlate with clinical outcome of melanoma patients treated with ipilimumab Cancer Immunol Immunother 63 247-257 https://doi.org/10.1007/s00262-013-1508-5

20. Kuang DM, Zhao Q, and Peng C, et al (2009) Activated monocytes in peritumoral stroma of hepatocellular carcinoma foster immune privilege and disease progression through PD-L1 J Exp Med 206 1327-1337 https://doi.org/10.1084/jem.20082173 PMID: 19451266 PMCID: 2715058

21. Schiavoni G, Sistigu A, and Valentini M, et al (2011) Cyclophosphamide synergizes with type I interferons through systemic dendritic cell reactivation and induction of immunogenic tumor apoptosis Cancer Res 71 768-778 https://doi.org/10.1158/0008-5472.CAN-102788

22. Soeda A, Morita-Hoshi Y, and Makiyama H, et al (2009) Regular dose of gemcitabine induces an increase in CD14+ monocytes and CD11c+ dendritic cells in patients with advanced pancreatic cancer Jpn J Clin Oncol 39 797-806 https://doi.org/10.1093/jjco/hyp112 PMID: 19797418

23. Lesterhuis WJ, Punt CJA, and Hato SV, et al (2011) Platinum-based drugs disrupt STAT6-mediated suppression of immune responses against cancer in humans and mice J Clin Invest 121 3100-3108 https://doi.org/10.1172/JCI43656 PMID: 21765211 PMCID: 3148725 
24. Pfannenstiel LW, Lam SSK, and Emens LA, et al (2010) Paclitaxel enhances early dendritic cell maturation and function through TLR4 signaling in mice Cell Immunol 263 79-87 https://doi.org/10.1016/j.cellimm.2010.03.001 PMID: 20346445 PMCID: 2862830

25. Kaneno R, Shurin GV, and Tourkova IL, et al (2009) Chemomodulation of human dendritic cell function by antineoplastic agents in low noncytotoxic concentrations J TransI Med https://doi.org/10.1186/1479-5876-7-58 PMID: 19591684 PMCID: 2716306

26. Tsavaris N, Kosmas C, and Vadiaka M, et al (2002) Immune changes in patients with advanced breast cancer undergoing chemotherapy with taxanes Br J Cancer 87 21-27 https://doi.org/10.1038/sj.bjc.6600347 PMID: 12085250 PMCID: 2364288

27. Wu J and Waxman DJ (2015) Metronomic cyclophosphamide eradicates large implanted GL261 gliomas by activating antitumor Cd8+ T-cell responses and immune memory Oncoimmunology [https://doi.org/10.1080/2162402X.2015.1005521] https://doi.org/10.1080/ 2162402X.2015.1005521

28. Lim SHS, Chua W, and Cheng C, et al (2014) Effect of neoadjuvant chemoradiation on tumor-infiltrating/associated lymphocytes in locally advanced rectal cancers Anticancer Res 34 6505-6513 PMID: 25368252

29. Demaria S, Volm MD, and Shapiro RL, et al (2001) Development of tumor-infiltrating lymphocytes in breast cancer after neoadjuvant paclitaxel chemotherapy Clin Cancer Res 7 3025-3030 PMID: 11595690

30. De Biasi AR, Villena-Vargas J, and Adusumilli PS (2014) Cisplatin-induced antitumor immunomodulation: a review of preclinical and clinical evidence Clin Cancer Res 20 5384-5391 https://doi.org/10.1158/1078-0432.CCR-14-1298 PMID: 25204552 PMCID: 4216745

31. Ghiringhelli F, Menard C, and Puig PE, et al (2007) Metronomic cyclophosphamide regimen selectively depletes CD4 +CD25+ regulatory T cells and restores T and NK effector functions in end stage cancer patients Cancer Immunol Immunother 56 641-648 https://doi. org/10.1007/s00262-006-0225-8

32. Li JY, Duan XF, and Wang LP, et al (2014) Selective depletion of regulatory t cell subsets by docetaxel treatment in patients with nonsmall cell lung cancer J Immunol Res https://doi.org/10.1155/2014/286170

33. Homma $\mathrm{Y}$, Taniguchi $\mathrm{K}$, and Nakazawa M, et al (2014) Changes in the immune cell population and cell proliferation in peripheral blood after gemcitabine-based chemotherapy for pancreatic cancer Clin Transl Oncol 16 330-335 https://doi.org/10.1007/s12094-013$1079-0$

34. Kashima $\mathrm{H}$, Momose $\mathrm{F}$, and Umehara $\mathrm{H}$, et al (2016) Epirubicin, identified using a novel luciferase reporter assay for foxp3 inhibitors, inhibits regulatory T cell activity PLoS One https://doi.org/10.1371/journal.pone.0156643

35. Roselli M, Cereda V, and di Bari MG, et al (2013) Effects of conventional therapeutic interventions on the number and function of regulatory T cells Oncoimmunology 2 e27025 https://doi.org/10.4161/onci.27025 PMID: 24353914 PMCID: 3862634

36. Gonzalez-Aparicio M, Alzuguren P, and Mauleon I, et al (2011) Oxaliplatin in combination with liver-specific expression of interleukin 12 reduces the immunosuppressive microenvironment of tumors and eradicates metastatic colorectal cancer in mice Gut $60341-349$ https://doi.org/10.1136/gut.2010.211722

37. Fujimura T, Kakizaki A, and Kambayashi Y, et al (2018) Cytotoxic antimelanoma drugs suppress the activation of M2 macrophages Exp Dermatol 27 64-70 https://doi.org/10.1111/exd.13417

38. Sevko A, Michels T, and Vrohlings M, et al (2013) Antitumor effect of paclitaxel is mediated by inhibition of myeloid-derived suppressor cells and chronic inflammation in the spontaneous melanoma model J Immunol 190 2464-2471 https://doi.org/10.4049/jimmunol.1202781 PMID: 23359505 PMCID: 3578135

39. Vincent J, Mignot G, and Chalmin F, et al (2010) 5-Fluorouracil selectively kills tumor-associated myeloid-derived suppressor cells resulting in enhanced T cell-dependent antitumor immunity Cancer Res 70 3052-3061 https://doi.org/10.1158/0008-5472.CAN-093690 PMID: 20388795 
40. Suzuki E, Kapoor V, and Jassar AS, et al (2005) Gemcitabine selectively eliminates splenic Gr-1+/CD11b + myeloid suppressor cells in tumor-bearing animals and enhances antitumor immune activity Clin Cancer Res 11 6713-6721 https://doi.org/10.1158/1078-0432. CCR-05-0883 PMID: 16166452

41. Casares N, Pequignot MO, and Tesniere A, et al (2005) Caspase-dependent immunogenicity of doxorubicin-induced tumor cell death J Exp Med 202 1691-1701 https://doi.org/10.1084/jem.20050915 PMID: 16365148 PMCID: 2212968

42. Tesniere A, Schlemmer F, and Boige V, et al (2010) Immunogenic death of colon cancer cells treated with oxaliplatin Oncogene 29 482-491 https://doi.org/10.1038/onc.2009.356

43. Nio Y, Hirahara N, and Minari Y, et al (2000) Induction of tumor-specific antitumor immunity after chemotherapy with cisplatin in mice bearing MOPC-104E plasmacytoma by modulation of MHC expression on tumor surface Anticancer Res 20 3293-3299 PMID: 11062756

44. Wan S, Pestka S, and Jubin RG, et al (2012) Chemotherapeutics and radiation stimulate MHC class i expression through elevated interferon-beta signaling in breast cancer cells PLoS One https://doi.org/10.1371/journal.pone.0032542

45. Gandhi L, Rodríguez-Abreu D, and Gadgeel S, et al (2018) Pembrolizumab plus chemotherapy in metastatic non-small-cell lung cancer N Engl J Med 378 2078-2092 https://doi.org/10.1056/NEJMoa1801005 PMID: 29658856

46. Paz-Ares L, Luft A, and Vicente D, et al (2018) Pembrolizumab plus chemotherapy for squamous non-small-cell lung cancer N Engl J Med 379 2040-2051 https://doi.org/10.1056/NEJMoa1810865 PMID: 30280635

47. Socinski MA, Jotte RM, and Cappuzzo F, et al (2018) Atezolizumab for first-line treatment of metastatic nonsquamous NSCLC N Engl J Med 378 2288-2301 https://doi.org/10.1056/NEJMoa1716948 PMID: 29863955

48. West H, McCleod M, and Hussein M, et al (2019) Atezolizumab in combination with carboplatin plus nab-paclitaxel chemotherapy compared with chemotherapy alone as first-line treatment for metastatic non-squamous non-small-cell lung cancer (IMpower130): a multicentre, randomised, open-label, phase 3 trial Lancet Oncol 20 924-937 https://doi.org/10.1016/S1470-2045(19)30167-6 PMID: 31122901

49. Horn L, Mansfield AS, and Szczęsna A, et al (2018) First-line atezolizumab plus chemotherapy in extensive-stage small-cell lung cancer N Engl J Med 379 2220-2229 https://doi.org/10.1056/NEJMoa1809064 PMID: 30280641

50. Burtness B, Harrington KJ, and Greil R, et al (2019) Pembrolizumab alone or with chemotherapy versus cetuximab with chemotherapy for recurrent or metastatic squamous cell carcinoma of the head and neck (KEYNOTE-048): a randomised, open-label, phase 3 study Lancet 394 1915-1928 https://doi.org/10.1016/S0140-6736(19)32591-7 PMID: 31679945

51. Lesterhuis WJ, Salmons J, and Nowak AK, et al (2013) Synergistic effect of CTLA-4 blockade and cancer chemotherapy in the induction of anti-tumor immunity PLoS One https://doi.org/10.1371/journal.pone.0061895 PMID: 23626745 PMCID: 3633941

52. lida $\mathrm{Y}$, Harashima N, and Motoshima T, et al (2017) Contrasting effects of cyclophosphamide on anti-CTL-associated protein 4 blockade therapy in two mouse tumor models Cancer Sci 108 1974-1984 https://doi.org/10.1111/cas.13337 PMID: 28787548 PMCID: 5623733

53. Nars MS, Kaneno R (2013) Immunomodulatory effects of low dose chemotherapy and perspectives of its combination with immunotherapy Int J Cancer 132 2471-2478 https://doi.org/10.1002/ijc.27801

54. Voorwerk L, Slagter M, and Horlings HM, et al (2019) Immune induction strategies in metastatic triple-negative breast cancer to enhance the sensitivity to PD-1 blockade: the TONIC trial Nat Med 25 920-928 https://doi.org/10.1038/s41591-019-0432-4 PMID: 31086347

55. Siena S, Sartore-Bianchi A, and Personeni N, et al (2019) Pembrolizumab in MMR-proficient metastatic colorectal cancer pharmacologically primed to trigger dynamic hypermutation status: The ARETHUSA trial J Clin Oncol 37 TPS2659-TPS2659 https://doi.org/10.1200/ JCO.2019.37.15_suppl.TPS2659 
56. Germano G, Lamba S, and Rospo G, et al (2017) Inactivation of DNA repair triggers neoantigen generation and impairs tumor growth Nature 552 1-5 https://doi.org/10.1038/nature24673

57. Barker HE, Paget JTE, and Khan AA, et al (2015) The tumor microenvironment after radiotherapy: mechanisms of resistance and recurrence Nat Rev Cancer 15 409-425 https://doi.org/10.1038/nrc3958 PMID: 26105538 PMCID: 4896389

58. Di Maggio FM, Minafra L, and Forte Gl, et al (2015) Portrait of inflammatory response to ionizing radiation treatment $J$ Inflamm (United Kingdom) https://doi.org/10.1186/s12950-015-0058-3

59. Mole RH (1953) Whole body irradiation; radiobiology or medicine? Br J Radiol 26 234-241 https://doi.org/10.1259/0007-1285-26305-234 PMID: 13042090

60. Demaria S, Ng B, and Devitt ML, et al (2004) lonizing radiation inhibition of distant untreated tumors (abscopal effect) is immune mediated Int J Radiat Oncol Biol Phys 58 862-870 https://doi.org/10.1016/j.jijrobp.2003.09.012 PMID: 14967443

61. Formenti SC, Rudqvist NP, and Golden E, et al (2018) Radiotherapy induces responses of lung cancer to CTLA-4 blockade Nat Med 24 1845-1851 https://doi.org/10.1038/s41591-018-0232-2 PMID: 30397353 PMCID: 6286242

62. Theelen W, H.Peulen@Nki.NI NF, and Lalezari F, et al (2018) Randomized phase II study of pembrolizumab after stereotactic body radiotherapy (SBRT) versus pembrolizumab alone in patients with advanced non-small cell lung cancer: the PEMBRO-RT study $J$ Clin Oncol 36 9023-9023 https://doi.org/10.1200/JCO.2018.36.15_suppl.9023

63. Antonia SJ, Villegas A, and Daniel D, et al (2017) Durvalumab after chemoradiotherapy in stage III non-small-cell lung cancer $\mathrm{N}$ Engl J Med 377 1919-1929 https://doi.org/10.1056/NEJMoa1709937 PMID: 28885881

64. Lugade AA, Moran JP, and Gerber SA, et al (2005) Local radiation therapy of b16 melanoma tumors increases the generation of tumor antigen-specific effector cells that traffic to the tumor J Immunol 174 7516-7523 https://doi.org/10.4049/jimmunol.174.12.7516 PMID: 15944250

65. Lee Y, Auh SL, and Wang Y, et al (2009) Therapeutic effects of ablative radiation on local tumor require CD8 + T cells: changing strategies for cancer treatment Blood 114 589-595 https://doi.org/10.1182/blood-2009-02-206870 PMID: 19349616 PMCID: 2713472

66. Dewan MZ, Galloway AE, and Kawashima N, et al (2009) Fractionated but not single-dose radiotherapy induces an immune-mediated abscopal effect when combined with anti-CTLA-4 antibody Clin Cancer Res 15 5379-5388 https://doi.org/10.1158/1078-0432.CCR09-0265 PMID: 19706802 PMCID: 2746048

67. Aryankalayil MJ, Makinde AY, and Gameiro SR, et al (2014) Defining molecular signature of pro-immunogenic radiotherapy targets in human prostate cancer cells Radiat Res 182 139-148 https://doi.org/10.1667/RR13731.1 PMID: 25003313 PMCID: 4216662

68. Patel D, Guo X, and Ng S, et al (2010) IgG isotype, glycosylation, and EGFR expression determine the induction of antibody-dependent cellular cytotoxicity in vitro by cetuximab Hum Antibodies 19 89-99 https://doi.org/10.3233/HAB-2010-0232 PMID: 21178280

69. Petricevic B, Laengle J, and Singer J, et al (2013) Trastuzumab mediates antibody-dependent cell-mediated cytotoxicity and phagocytosis to the same extent in both adjuvant and metastatic HER2/neu breast cancer patients J Transl Med https://doi.org/10.1186/14795876-11-307 PMID: 24330813 PMCID: $\underline{4029549}$

70. Bibeau F, Lopez-Crapez E, and Fiore F Di, et al (2009) Impact of fcyRlla-fc $\gamma R$ Illla polymorphisms and KRAS mutations on the clinical outcome of patients with metastatic colorectal cancer treated with cetuximab plus irinotecan J Clin Oncol 27 1122-1129 https://doi. org/10.1200/JCO.2008.18.0463 PMID: 19164213

71. Lee $\mathrm{CH}$, Romain G, and Yan W, et al (2017) IgG Fc domains that bind C1q but not effector Fc3 receptors delineate the importance of complement-mediated effector functions Nat Immunol 18 889-898 https://doi.org/10.1038/ni.3770 PMID: 28604720 PMCID: 6015732 
72. Srivastava RM, Trivedi S, and Concha-Benavente F, et al (2015) Stat1-induced HLA class i upregulation enhances immunogenicity and clinical response to anti-EGFR mab cetuximab therapy in HNC patients Cancer Immunol Res 3 936-945 https://doi.org/10.1158/23266066.CIR-15-0053 PMID: 25972070 PMCID: 4526378

73. Sabbatino F, Wang Y, and Scognamiglio G, et al (2016) Antitumor activity of BRAF inhibitor and IFN×alpha; Combination in BRAFmutant melanoma J Natl Cancer Inst https://doi.org/10.1093/jnci/djv435

74. Pollack BP, Sapkota B, and Cartee TV. (2011) Epidermal growth factor receptor inhibition augments the expression of MHC class I and II genes Clin Cancer Res 17 4400-4413 https://doi.org/10.1158/1078-0432.CCR-10-3283 PMID: 21586626

75. Sapkota B, Hill CE, and Pollack BP (2013) Vemurafenib enhances MHC induction in BRAFV600E homozygous melanoma cells Oncoimmunology https://doi.org/10.4161/onci.22890 PMCID: 3583938

76. Boni A, Cogdill AP, and Dang P, et al (2010) Selective BRAFV600E inhibition enhances T-cell recognition of melanoma without affecting lymphocyte function Cancer Res 70 5213-5219 https://doi.org/10.1158/0008-5472.CAN-10-0118 PMID: 20551059

77. Atefi M, Avramis E, and Lassen A, et al (2014) Effects of MAPK and PI3K pathways on PD-L1 expression in melanoma Clin Cancer Res 20 3446-3457 https://doi.org/10.1158/1078-0432.CCR-13-2797 PMID: 24812408 PMCID: 4079734

78. Jiang X, Zhou J, and Giobbie-Hurder A, et al (2013) The activation of MAPK in melanoma cells resistant to BRAF inhibition promotes PD-L1 expression that is reversible by MEK and PI3K inhibition Clin Cancer Res 19 598-609 https://doi.org/10.1158/1078-0432.CCR12-2731

79. Zaiss DMW, van Loosdregt J, and Gorlani A, et al (2013) Amphiregulin enhances regulatory T cell-suppressive function via the epidermal growth factor receptor Immunity 38 275-284 https://doi.org/10.1016/j.immuni.2012.09.023 PMID: 23333074 PMCID: 3582723

80. Wilmott JS, Long GV, and Howle JR, et al (2012) Selective BRAF inhibitors induce marked T-cell infiltration into human metastatic melanoma Clin Cancer Res 18 386-1394 https://doi.org/10.1158/1078-0432.CCR-11-2479

81. Garrido G, Rabasa A, and Sánchez B, et al (2011) Induction of immunogenic apoptosis by blockade of epidermal growth factor receptor activation with a specific antibody J Immunol 187 4954-4966 https://doi.org/10.4049/jimmunol.1003477 PMID: 21984704

82. Deken MA, Gadiot J, and Jordanova ES, et al (2016) Targeting the MAPK and PI3K pathways in combination with PD1 blockade in melanoma Oncoimmunology https://doi.org/10.1080/2162402X.2016.1238557

83. Müller P, Kreuzaler M, and Khan T, et al (2015) Trastuzumab emtansine (T-DM1) renders HER2 + breast cancer highly susceptible to CTLA-4/PD-1 blockade Sci Transl Med https://doi.org/10.1126/scitranslmed.aac4925

84. Ribas A, Hodi FS, and Callahan M, et al (2013) Hepatotoxicity with combination of vemurafenib and ipilimumab N Engl J Med 368 1365-1366 https://doi.org/10.1056/NEJMc1302338 PMID: 23550685

85. Amin A, Lawson DH, and Salama AKS, et al (2016) Phase II study of vemurafenib followed by ipilimumab in patients with previously untreated BRAF-mutated metastatic melanoma J Immunother Cancer https://doi.org/10.1186/s40425-016-0148-7 PMID: 27532019 PMCID: 4986368

86. Minor DR, Puzanov I, and Callahan MK, et al (2015) Severe gastrointestinal toxicity with administration of trametinib in combination with dabrafenib and ipilimumab Pigment Cell Melanoma Res 28 611-612 https://doi.org/10.1111/pcmr.12383 PMID: 25996827 PMCID: 4744965

87. Ascierto PA, Ferrucci PF, and Fisher R, et al (2019) Dabrafenib, trametinib and pembrolizumab or placebo in BRAF-mutant melanoma Nat Med 25 941-946 https://doi.org/10.1038/s41591-019-0448-9 PMID: 31171878

88. Solomon BJ, Besse B, and Bauer TM, et al (2018) Lorlatinib in patients with ALK-positive non-small-cell lung cancer: results from a global phase 2 study Lancet Oncol 19 1654-1667 https://doi.org/10.1016/S1470-2045(18)30649-1 PMID: 30413378 
89. Peters S, Camidge DR, and Shaw AT, et al (2017) Alectinib versus crizotinib in untreated ALK -positive non-small-cell lung cancer N Engl J Med 377 829-838 https://doi.org/10.1056/NEJMoa1704795 PMID: 28586279

90. Ramalingam SS, Vansteenkiste J, and Planchard D, et al (2019) Overall survival with osimertinib in untreated, EGFR-mutated advanced NSCLC N Engl J Med https://doi.org/10.1056/NEJMoa1913662

91. Mazieres J, Drilon A, and Lusque A, et al (2019) Immune checkpoint inhibitors for patients with advanced lung cancer and oncogenic driver alterations: results from the IMMUNOTARGET registry Ann Oncol 30 1321-1328 https://doi.org/10.1093/annonc/mdz167 PMID: 31125062 PMCID: 7389252

92. Offin M, Rizvi H, and Tenet M, et al (2019) Tumor mutation burden and efficacy of EGFR-tyrosine kinase inhibitors in patients with EGFR-mutant lung cancers Clin Cancer Res 25 1063-1069 https://doi.org/10.1158/1078-0432.CCR-18-1102 PMCID: 6347551

93. Spigel DR, Schrock AB, and Fabrizio D, et al (2016) Total mutation burden (TMB) in lung cancer (LC) and relationship with response to PD-1/PD-L1 targeted therapies J Clin Oncol 34 9017-9017 https://doi.org/10.1200/JCO.2016.34.15_suppl.9017

94. Busch SE, Hanke ML, and Kargl J, et al (2016) Lung cancer subtypes generate unique immune responses J Immunol 197 $4493-4503$ https://doi.org/10.4049/jimmunol.1600576 PMID: 27799309 PMCID: 5116260

95. Chen N, Fang W, and Zhan J, et al (2015) Upregulation of PD-L1 by EGFR activation mediates the immune escape in EGFR-driven NSCLC: implication for optional immune targeted therapy for NSCLC patients with EGFR mutation J Thorac Oncol 10 910-923 https:// doi.org/10.1097/JTO.0000000000000500 PMID: 25658629

96. Garassino MC, Cho BC, and Kim JH, et al (2018) Durvalumab as third-line or later treatment for advanced non-small-cell lung cancer (ATLANTIC): an open-label, single-arm, phase 2 study Lancet Oncol 19 521-536 https://doi.org/10.1016/S1470-2045(18)30144-X PMID: 29545095

97. Garassino MC, Gelibter AJ, and Grossi F, et al (2018) Italian nivolumab expanded access program in nonsquamous non-small cell lung cancer patients: Results in never-smokers and EGFR-mutant patients J Thorac Oncol 13 1146-1155 https://doi.org/10.1016/j. jtho.2018.04.025 PMID: 29730379

98. Gettinger S, Hellmann MD, and Chow LQM, et al (2018) Nivolumab plus erlotinib in patients with EGFR-mutant advanced NSCLC J Thorac Oncol 13 1363-1372 https://doi.org/10.1016/j.jtho.2018.05.015 PMID: 29802888

99. Gibbons DL, Chow LQ, and Kim DW, et al (2016) 570 Efficacy, safety and tolerability of MEDI4736 (durvalumab [D]), a human IgG1 anti-programmed cell death-ligand-1 (PD-L1) antibody, combined with gefitinib (G): a phase I expansion in TKI-naïve patients (pts) with EGFR mutant NSCLC J Thorac Oncol 11 S79 https://doi.org/10.1016/S1556-0864(16)30171-X

100.Chih J, Yang H, and Shepherd FA, et al (2019) Osimertinib plus durvalumab versus osimertinib monotherapy in EGFR T790M-positive NSCLC following previous EGFR TKI therapy: CAURAL brief report J Thorac Oncol 14(5) 933-939 https://doi.org/10.1016/j. jtho.2019.02.001

101. Vladimer GI, Snijder B, and Krall N, et al (2017) Global survey of the immunomodulatory potential of common drugs Nat Chem Biol 13 681-690 https://doi.org/10.1038/nchembio.2360 PMID: 28437395 PMCID: 5438060

102.Spigel DR, Reynolds C, and Waterhouse D, et al (2018) Phase 1/2 study of the safety and tolerability of nivolumab plus crizotinib for the first-line treatment of anaplastic lymphoma kinase translocation - positive advanced non-small cell lung cancer (CheckMate 370 ) J Thorac Oncol 13 682-688 https://doi.org/10.1016/j.jtho.2018.02.022 PMID: 29518553

103.Felip E, De Braud FG, and Maur M, et al (2017) Ceritinib plus nivolumab (NIVO) in patients (pts) with anaplastic lymphoma kinase positive (ALK+) advanced non-small cell lung cancer (NSCLC) J Clin Oncol 35 2502-2502 https://doi.org/10.1200/JCO.2017.35.15_ suppl.2502

104.Kim D-W, Gadgeel SM, and Gettinger SN, et al (2018) Safety and clinical activity results from a phase lb study of alectinib plus atezolizumab in ALK + advanced NSCLC (aNSCLC). J Clin Oncol 36 9009-9009 https://doi.org/10.1200/JC0.2018.36.15_suppl.9009 
105.Ferris RL, Lenz HJ, and Trotta AM, et al (2018) Rationale for combination of therapeutic antibodies targeting tumor cells and immune checkpoint receptors: Harnessing innate and adaptive immunity through IgG1 isotype immune effector stimulation Cancer Treat Rev 63 48-60 https://doi.org/10.1016/j.ctrv.2017.11.008

106.Wilmott JS, Hersey P, and Long GV, et al (2015) Synergistic effects of MAPK and immune checkpoint inhibitors in melanoma: what is the best combination strategy? Melanoma Manag 2 15-19 https://doi.org/10.2217/mmt.14.26 PMID: 30190826 PMCID: 6094588

107.Sandhu SK, Atkinson VG, and Cao MG, et al (2019) 1358PInterim analysis of a phase lb study of cobimetinib plus atezolizumab in patients with advanced BRAFV600 wild type melanoma progressing on prior anti-PD-L1 therapy Ann Oncol https://doi.org/10.1093/ annonc/mdz255.046

108. Keating GM (2014) Bevacizumab: a review of its use in advanced cancer Drugs 74 1891-1925 https://doi.org/10.1007/s40265-0140302-9 PMID: 25315029

109.Ohm JE and Carborne DP (2001) VEGF as a mediator of tumor-associated immunodeficiency Immunol Res 23 263-272 https://doi. org/10.1385/IR:23:2-3:263 PMID: 11444391

110.Gabrilovich D, Ishida T, and Oyama T, et al (1998) Vascular endothelial growth factor inhibits the development of dendritic cells and dramatically affects the differentiation of multiple hematopoietic lineages in vivo Blood 92 4150-4166 https://doi.org/10.1182/blood. V92.11.4150 PMID: $\underline{9834220}$

111.Elamin YY, Rafee S, and Toomey S, et al (2015) Immune effects of bevacizumab: killing two birds with one stone Cancer Microenviron 8 15-21 https://doi.org/10.1007/s12307-014-0160-8 PMCID: 4449343

112. Kwilas AR, Ardiani A, and Donahue RN, et al (2014) Dual effects of a targeted small-molecule inhibitor (cabozantinib) on immunemediated killing of tumor cells and immune tumor microenvironment permissiveness when combined with a cancer vaccine $J$ Transl Med https://doi.org/10.1186/s12967-014-0294-y PMID: 25388653 PMCID: 4236498

113.Ko JS, Zea AH, and Rini BI, et al (2009) Sunitinib mediates reversal of myeloid-derived suppressor cell accumulation in renal cell carcinoma patients Clin Cancer Res 15 2148-2157 https://doi.org/10.1158/1078-0432.CCR-08-1332 PMID: 19276286

114.Finke JH, Rini B, and Ireland J, et al (2008) Sunitinib reverses type-1 immune suppression and decreases T-regulatory cells in renal cell carcinoma patients Clin Cancer Res 14 6674-6682 https://doi.org/10.1158/1078-0432.CCR-07-5212 PMID: 18927310

115. Yasuda S, Sho M, and Yamato I, et al (2013) Simultaneous blockade of programmed death 1 and vascular endothelial growth factor receptor 2 (VEGFR2) induces synergistic anti-tumor effect in vivo Clin Exp Immunol 172 500-506 https://doi.org/10.1111/cei.12069 PMID: 23600839 PMCID: 3646450

116.Amin A, Plimack ER, and Infante JR, et al (2014) Nivolumab (anti-PD-1; BMS-936558, ONO-4538) in combination with sunitinib or pazopanib in patients (pts) with metastatic renal cell carcinoma (mRCC) J Clin Oncol 32 5010-5010 https://doi.org/10.1200/ $\underline{\text { jco.2014.32.15_suppl.5010 }}$

117.Dudek AZ, Sica RA, and Sidani A, et al (2016) Phase lb study of pembrolizumab in combination with bevacizumab for the treatment of metastatic renal cell carcinoma: Big Ten Cancer Research Consortium BTCRC-GU14-003 J Clin Oncol 34 559-559 https://doi. org/10.1200/jco.2016.34.2_suppl.559

118.Sznol M, McDermott DF, and Jones SF, et al (2015) Phase lb evaluation of MPDL3280A (anti-PDL1) in combination with bevacizumab (bev) in patients (pts) with metastatic renal cell carcinoma (mRCC) J Clin Oncol 33 410-410 https://doi.org/10.1200/jco.2015.33.7. suppl.410

119. Motzer RJ, Penkov K, and Haanen J, et al (2019) Avelumab plus axitinib versus sunitinib for advanced renal-cell carcinoma N Engl J Med 380 1103-1115 https://doi.org/10.1056/NEJMoa1816047 PMID: 30779531 PMCID: 6716603

120. Rini BI, Plimack ER, and Stus V, et al (2019) Pembrolizumab plus axitinib versus sunitinib for advanced renal-cell carcinoma N Engl J Med 380 1116-1127 https://doi.org/10.1056/NEJMoa1816714 PMID: 30779529 
121.Cheng A-L, Qin S, and Ikeda M, et al (2019) LBA3IMbrave150: efficacy and safety results from a ph III study evaluating atezolizumab (atezo) + bevacizumab (bev) vs sorafenib (Sor) as first treatment (tx) for patients (pts) with unresectable hepatocellular carcinoma (HCC) Ann Oncol https://doi.org/10.1093/annonc/mdz446.002

122.Fife BT and Bluestone JA (2008) Control of peripheral T-cell tolerance and autoimmunity via the CTLA-4 and PD-1 pathways Immunol Rev 224 166-182 https://doi.org/10.1111/j.1600-065X.2008.00662.x PMID: 18759926

123.Larkin J, Chiarion-Sileni V, and Gonzalez R, et al (2019) Five-year survival with combined nivolumab and ipilimumab in advanced melanoma N Engl J Med 381 1535-1546 https://doi.org/10.1056/NEJMoa1910836 PMID: 31562797

124.Motzer RJ, Rini Bl, and McDermott DF, et al (2019) Nivolumab plus ipilimumab versus sunitinib in first-line treatment for advanced renal cell carcinoma: extended follow-up of efficacy and safety results from a randomised, controlled, phase 3 trial Lancet Oncol 20 1370-1385 https://doi.org/10.1016/S1470-2045(19)30413-9 PMID: 31427204 PMCID: 7497870

125.Overman MJ, Lonardi S, and Wong KYM, et al (2018) Durable clinical benefit with nivolumab plus ipilimumab in DNA mismatch repair-deficient/microsatellite instability-high metastatic colorectal cancer J Clin Oncol 36 773-779 https://doi.org/10.1200/ JCO.2017.76.9901 PMID: 29355075

126. Mazzarella L, Duso BA, and Trapani D, et al (2019) The evolving landscape of 'next-generation' immune checkpoint inhibitors: a review Eur J Cancer 117 14-31 https://doi.org/10.1016/j.ejca.2019.04.035 PMID: 31229946

127.Andrews LP, Yano H, Vignali DAA (2019) Inhibitory receptors and ligands beyond PD-1, PD-L1 and CTLA-4: breakthroughs or backups Nat Immunol https://doi.org/10.1038/s41590-019-0512-0 PMID: 31611702 PMCID: 6380945

128. Horuk R (2009) Chemokine receptor antagonists: overcoming developmental hurdles Nat Rev Drug Discov 8 23-33 https://doi. org/10.1038/nrd2734

129.Prendergast GC, Malachowski WP, and DuHadaway JB, et al (2017) Discovery of IDO1 inhibitors: from bench to bedside Cancer Res 77 6795-6811 https://doi.org/10.1158/0008-5472.CAN-17-2285 PMID: 29247038 PMCID: 6021761

130.André $P$, Denis $C$, and Soulas C, et al (2018) Anti-NKG2A mAb is a checkpoint inhibitor that promotes anti-tumor immunity by unleashing both T and NK cells Cell 175 1731-1743.e13 https://doi.org/10.1016/j.cell.2018.10.014 PMID: 30503213 PMCID: 6292840

131.Cannarile MA, Weisser M, and Jacob W, et al (2017) Colony-stimulating factor 1 receptor (CSF1R) inhibitors in cancer therapy J Immunother Cancer https://doi.org/10.1186/s40425-017-0257-y PMID: 28716061 PMCID: 5514481

132.Ascierto PA, Melero I, and Bhatia S, et al (2017) Initial efficacy of anti-lymphocyte activation gene-3 (anti-LAG-3; BMS-986016) in combination with nivolumab (nivo) in pts with melanoma (MEL) previously treated with anti-PD-1/PD-L1 therapy J Clin Oncol 35 9520-9520 https://doi.org/10.1200/JCO.2017.35.15_suppl.9520

133.Curigliano G, Gelderblom H, and Mach N, et al (2019) Abstract CT183: Phase (Ph) I/Il study of MBG453 spartalizumab (PDR001) in patients (pts) with advanced malignancies Cancer Res 79 CT183-CT183

134.Mach N, Curigliano G, and Santoro A, et al (2019) 1202PPhase (Ph) II study of MBG453 + spartalizumab in patients (pts) with nonsmall cell lung cancer (NSCLC) and melanoma pretreated with anti-PD-1/L1 therapy Ann Oncol https://doi.org/10.1093/annonc/ $\mathrm{mdz} 253.028$

135.Long GV, Dummer R, and Hamid O, et al (2019) Epacadostat plus pembrolizumab versus placebo plus pembrolizumab in patients with unresectable or metastatic melanoma (ECHO-301/KEYNOTE-252): a phase 3, randomised, double-blind study Lancet Oncol 20 1083-1097 https://doi.org/10.1016/S1470-2045(19)30274-8 PMID: 31221619

136. Conforti F, Pala L, and Bagnardi V, et al (2018) Cancer immunotherapy efficacy and patients' sex: a systematic review and meta-analysis Lancet Oncol 19 737-746 https://doi.org/10.1016/S1470-2045(18)30261-4 PMID: 29778737 
137.Norum J and Nieder C (2018) Tobacco smoking and cessation and PD-L1 inhibitors in non-small cell lung cancer (NSCLC): a review of the literature ESMO Open https://doi.org/10.1136/esmoopen-2018-000406 PMID: 30305940 PMCID: 6173248

138. Reck M, Rodríguez-Abreu D, and Robinson AG, et al (2019) Updated analysis of KEYNOTE-024: Pembrolizumab versus platinum-based chemotherapy for advanced non-small-cell lung cancer with PD-L1 tumor proportion score of 50\% or greater J Clin Oncol $37537-546$ https://doi.org/10.1200/JCO.18.00149 PMID: 30620668

139.Gadgeel SM, Garassino MC, and Esteban E, et al (2019) KEYNOTE-189: updated OS and progression after the next line of therapy (PFS2) with pembrolizumab (pembro) plus chemo with pemetrexed and platinum vs placebo plus chemo for metastatic nonsquamous NSCLC J Clin Oncol 379013 https://doi.org/10.1200/JCO.2019.37.15_suppl.9013

140.Schmid P, Adams S, and Rugo HS, et al (2018) Atezolizumab and nab-paclitaxel in advanced triple-negative breast cancer N Engl J Med 379 2108-2121 https://doi.org/10.1056/NEJMoa1809615 PMID: 30345906

141.Schmid P, Rugo HS, and Adams S, et al (2019) Atezolizumab plus nab-paclitaxel as first-line treatment for unresectable, locally advanced or metastatic triple-negative breast cancer (IMpassion130): updated efficacy results from a randomised, double-blind, placebo-controlled, phase 3 trial Lancet Oncol https://doi.org/10.1016/S1470-2045(19)30689-8 PMID: 31786121

142. Wolchok JD, Chiarion-Sileni V, and Gonzalez R, et al (2017) Overall survival with combined nivolumab and ipilimumab in advanced melanoma N Engl J Med 377 1345-1356 https://doi.org/10.1056/NEJMoa1709684 PMID: 28889792 PMCID: 5706778 